\title{
Sistemski vidik priprave programa varstva okolja oziroma lokalne Agende 21
}

\author{
Emil Šterbenk \\ Mag., ERICo Velenje, Inštitut za ekološke raziskave, Koroška 58, \\ 3320 Velenje, Slovenija \\ e-mil: sterbenk@erico.si

\section{Zoran Pavšek} \\ ERICo Velenje, Inštitut za ekološke raziskave, Koroška 58, \\ 3320 Velenje, Slovenija \\ e-mail: zoran.pavsek@erico.si
}

\section{Izvleček}

Program varstva okolja in Lokalna agenda 21 sta dokumenta, namenjena uvajanju trajnostnega razvoja $v$ lokalne skupnosti. Oba morata biti realna in izvedljiva. Pri njuni pripravi in realizaciji morajo sodelovati lokalna skupnost, javnost, pomembnejša podjetja in organizacije. V tem članku so podani vsebina programov varstva okolja in Lokalne agende 21 ter praktične izkušnje in nasveti izvajalcev.

Ključne besede: program varstva okolja, lokalna agenda 21, razvojni program

\section{Overall View of the preparation of an Environmental Protection Programme or Local Agenda 21}

\begin{abstract}
An Environmental Protection Programme and a Local Agenda 21 are documents intended for promotion of sustainable development in the local co-mmunities. Both documents should be realistic and capable of implementation. The local community, the public and all the main companies and organisations should be involved in the preparation and the realisation of the programmes. In this contribution the contents of the programmes and some experiences and advice to those taking part are discussed.
\end{abstract}

Key words: environmental protection programme, local agenda 21, development programme 


\section{UVOD}

Zadnja tri desetletja dvajsetega stoletja so bila $\mathrm{v}$ znamenju povečanih okoljskih pritiskov naraščajočega prebivalstva, ki je ob začetku 21. stoletja štelo šest milijard ljudi. Skozi to obdobje pa je rasla tudi zavest, da so viri na Zemlji omejeni, in da je z njimi potrebno trajnostno gospodariti (Laws 2000). Leta 1992 so Združeni narodi v Riu de Janeiru sprejeli Agendo 21, planetarni program trajnostnega razvoja, katerega namen je preprečiti rušenje ravnovesja med posameznimi pokrajinskimi elementi zaradi čedalje večjih antropogenih obremenitev. Dosedanji razvojni modeli so bili ozko tržno zasnovani in niso upoštevali okoljskih posledic gospodarskega razvoja. Agenda 21 pa stroške okolja in izčrpavanja naravnih virov celovito vključuje $\mathrm{v}$ gospodarsko načrtovanje. Izkazalo se je, da se globalni razvojni cilji lahko uresničijo zgolj na podlagi mreže lokalnih izboljšav, zato lokalne skupnosti povsod po svetu pripravljajo lokalne agende 21. V 28. poglavju Agende 21 je vključen poziv vsem lokalnim skupnostim, naj pripravijo svoje lastne Lokalne agende 21, v katerih naj splošne cilje Agende 21 preoblikujejo v konkretne načrte in dejavnosti za svoje posebne in značilne razmere (Hewitt, 1997).

Lokalna agenda 21 je pot $\mathrm{k}$ trajnostnemu razvoju, $\mathrm{v}$ katerem so enakomerno zastopani okoljski, gospodarski in socialni vidiki. Lokalna agenda je realen in izvedljiv razvojni program lokalne skupnosti, ki se ne konča, ampak se ciklično nadaljuje. Primerneje je reči, da je to proces nenehnih izboljšav za dosego trajnostnega razvoja.

V slovenski zakonodaji se pojem lokalna agenda (̌se) nikjer ne pojavlja. Zakon o varstvu okolja (Ur.l RS 32/93), govori o programih varstva okolja lokalnih skupnosti in skupin lokalnih skupnosti. Zakon v 50. členu predvideva, da mestne občine sprejmejo programe varstva okolja in operativne programe za svoje območje. Lokalni program varstva okolja vsebuje cilje, usmeritve in strategijo varstva okolja in rabe naravnih dobrin za najmanj deset let (VilerKovač in drugi, 1999). Obravnaval naj bi naslednja poglavja: stanje okolja in njegovih obremenitev ter njihov vpliv na zdravje prebivalstva, ovrednotenje stanja okolja, posameznih naravnih dobrin in njihove ogroženosti, dolgoročne projekcije trendov in stanja okolja, dosegljive cilje in načine njihovega uresničevanja, potrebna sredstva in njihove vire, prednostne naloge in projekte, smernice za razvoj dejavnosti in javnih služb varstva okolja ter analize pričakovanih stroškov in koristi. Vsekakor je Lokalna agenda 21 program, ki zajema vse naštete dejavnosti. Toda vsebina lokalne agende je širša kot vsebina lokalnega programa varstva okolja. Več slovenskih občin se je doslej odločilo za program varstva okolja kot za lokalno agendo. 
Tako program varstva okolja kot lokalna agenda sta zelo kompleksna projekta. Pri njuni pripravi moramo identificirati najpomembnejše družbeno in naravnogeografske dejavnike razvoja, uskladiti poglede različnih strok, dejavnosti in javnosti ter pripraviti uravnotežen akcijski program. To pa so tematike, ki jih geografi dobro obvladamo, zato je geograf lahko uspešen nosilec oziroma sodelavec v nalogi. Celovito geografsko poznavanje pokrajine in procesov, ki jo oblikujejo, lahko pripomore k večji gospodarski uspešnosti, socialni pravičnosti in okoljski odgovornosti razvojnih akterjev. ERICo Velenje, inštitut za ekološke raziskave trenutno pripravlja oziroma je pripravil vrsto programov lokalnih skupnosti v smeri trajnostnega razvoja in pri vseh so sodelovali geografi. Raziskovalci so pri aplikativnem delu naleteli na različne probleme, ki so jih v večini primerov uspešno rešili. $\mathrm{V}$ tem prispevku so podani praktične izkušnje in napotki.

Preglednica: Reference ERICa Velenje na področju programov varstva okolja in lokalnih agend

\begin{tabular}{|l|l|}
\hline Program varstva okolja, Lokalna agenda & Faza \\
\hline Kataster onesnaženosti zraka v občini Velenje & Podlaga za sanacijski program \\
\hline Sanacijski program Vode občine Velenje & Zaključen projekt, izvajanje \\
\hline $\begin{array}{l}\text { Gospodarjenje z vodami v pridobivalnem prostoru } \\
\text { premogovnika Velenje }\end{array}$ & Zaključen projekt, izvajanje \\
\hline Sanacijski program za tla v mestni občini Velenje & $\begin{array}{l}\text { Izdelane strokovne osnove in } \\
\text { osnutek odloka }\end{array}$ \\
\hline Program varstva okolja za občino Žalec-LA 21 Žalec & $\begin{array}{l}\text { Zaključen, predstavitev za Svet } \\
\text { občine: 3. oktober 2002 }\end{array}$ \\
\hline LA za mestno občino Velenje & Zaključna \\
\hline LA 21 za občino Šmartno ob Paki & $\begin{array}{l}\text { Delavnice na področjih okolja, } \\
\text { gospodarstva in sociale }\end{array}$ \\
\hline LA 21 za občino Črna na Koroškem & $\begin{array}{l}\text { Poročilo o stanju naravnega in } \\
\text { družbenega okolja }\end{array}$ \\
\hline LA 21 za občino Mežica & $\begin{array}{l}\text { Poročilo o stanju naravnega in } \\
\text { družbenega okolja }\end{array}$ \\
\hline LA 21 za občino Celje & $\begin{array}{l}\text { Priprava poročila o stanju } \\
\text { naravnega in družbenega okolja }\end{array}$ \\
\hline Program varstva okolja za občino Jesenice & Podpis pogodbe \\
\hline
\end{tabular}

\section{LOKALNA AGENDA 21}

Pojem lokalna agenda pomeni celovit lokalni razvojni program. Morda bi bil boljši izraz proces, saj dejansko ne gre za program za katerega se odločimo, da ga bomo pripravili, načrtovali, izvedli in zaključili. $\mathrm{V}$ resnici je to proces, $\mathrm{v}$ 
katerem identificiramo probleme, zastavimo cilje, jih rangiramo po pomembnosti, izdelamo programe, jih izvedemo in ponovno ovrednotimo ter se vrnemo na izhodišče ali katero od vmesnih faz (Hewitt 1997 str. 17). Lokalno agendo lahko ponazorimo z Demingovim krogom (slika 1). Krog ponazarja vrtenje oziroma cikličnost procesa: načrtuj, izvedi, preveri, ukrepaj. Po vsakem obratu pa smo na višjem nivoju oziroma bliže trajnostnemu razvoju.

Lokalna agenda je tudi pot majhnih korakov proti planetarnemu izboljšanju, saj z lokalnimi izboljšavami dajemo svoj prispevek tudi na globalno raven.

Slika 1: Lokalna agenda 21 ponazorjena z Demingovim krogom

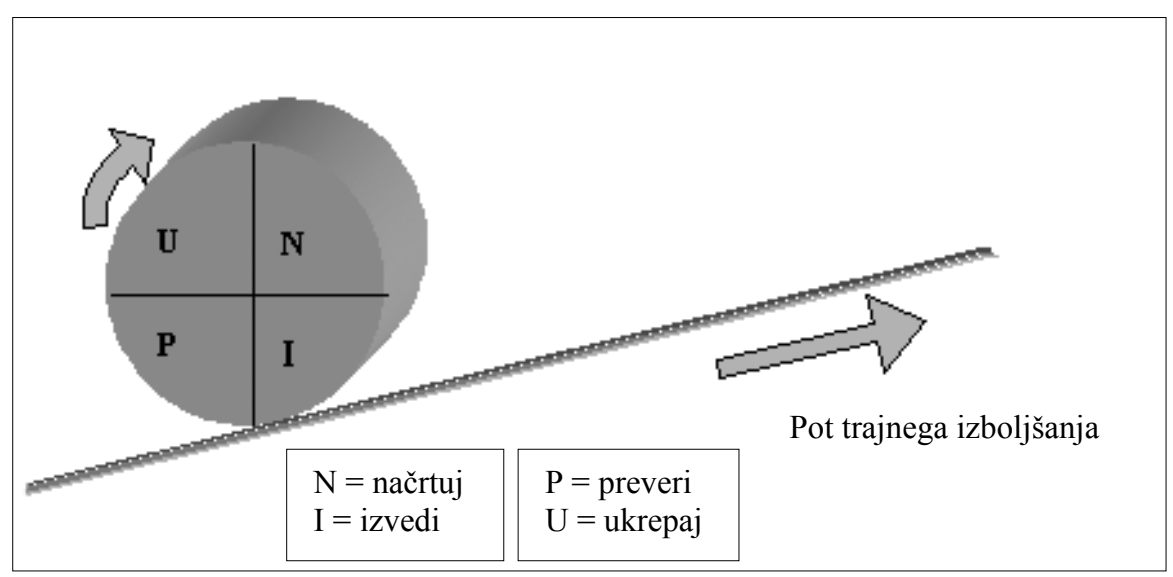

Lokalna agenda je celovit program lokalne skupnosti tako na gospodarskem kot socialnem in okoljskem področju. Program varstva okolja se gospodarstva in sociale dotika v manjšem obsegu. Drugo pojmovanje je: Lokalna agenda zeleni razvojni načrt. Tukaj večkrat prihaja do različnih razumevanj tega pojma. Po mnenju enih je to okoljsko obarvan razvojni načrt, drugi pa ga spet pojmujejo izključno kot program varstva okolja.

\subsection{Koristi za lokalno skupnost in njene razvojne nosilce}

Lokalna agenda še zdaleč ni namenjena samo izboljšanju okolja, ampak pomeni napredek na vseh področjih življenja, dela in bivanja $v$ lokalni skupnosti. Koristi za občino, ki se je odločila, da vpelje lokalno agendo, so:

- ugotavljanje ključnih občinskih problemov na področju gospodarstva, sociale in okolja, 
- usmerjanje dela uprave in sredstev v smotrne projekte,

- hitrejše reševanje problemov (lokalnih in tistih, ki segajo čez meje občine),

- boljše sodelovanje z občani (javnost in transparentnost dela, večje zaupanje javnosti),

- promocija občine,

- pridobivanje dodatnih sredstev od drugih organizacij na podlagi sprejetih programov (država, Evropska zveza).

Vrsto koristi imajo zaradi izvajanja lokalne agende občani:

- višja stopnja obveščenosti in osveščenosti,

- širši vpogled v delo lokalne skupnosti,

- možnost aktivnega sodelovanja in udejstvovanja pri posameznih projektih (predstavitev problemov »navadnih ljudi«),

- aktivno sodelovanje društev in organizacij pri oblikovanju občinske razvojne politike.

Če želimo pripraviti celovit program, moramo v njegovo pripravo vključiti podjetja, ki obratujejo oziroma delujejo na območju občine. Seveda pa imajo od lokalne agende oziroma programa varstva okolja koristi tudi podjetja:

- sodelovanje z javnostjo,

- transparentnost njihovega dela,

- ugotavljanje mnenja občanov o podobi in vplivih podjetij,

- s saniranjem najbolj perečih problemov pridobiti zaupanje javnosti,

- promocija.

\section{METODOLOGIJA}

Za vpeljavo programa varstva okolja ali lokalne agende je pomembnih več metodologij. Prva je organizacijska, sledi metodologija izdelave programa, vsaka faza pa ima še svojo metodologijo. V vsakem primeru je v proces potrebno vključiti veliko število sodelavcev, zato se je tega potrebno lotiti zelo premišljeno.

\subsection{Organizacija}

Najpomembnejši cilj je pripraviti program, ki bo zaživel v praksi in bo prinesel izboljšave na različnih področjih dela in bivanja. Temu primerno velja tudi izbirati sodelavce. Potrebno je pritegniti različne strokovnjake, ključne ljudi iz podjetij, organizacij in društev, državne uprave, lokalne skupnosti ter druge zain- 
teresirane posameznike. Delovno skupino potem poimenujemo. Na ERICu Velenje smo izbrali ime skupina zainteresiranih udeležencev. Le-ta naj ne bi štela več kot 40 ljudi. V primeru, da jih je manj pa je včasih težko organizirati predavanja, razprave in delavnice, saj nikoli ne moremo zagotoviti $100 \%$ udeležbe (Svetina in sodelavci 2000, Pavšek in sodelavci 2000).

Navadno je pobudnik ustanovitve skupine občina, skupina pa deluje kot samostojno delovno telo in je preko predstavnikov lokalne oblasti, ki so vanjo vključeni, neposredno povezana $\mathrm{z}$ občinskim svetom. Sodelavce izbiramo tako, da skupina kar najbolje predstavlja lokalno skupnost. V skupini naj bi bila spola enakopravno zastopana.

Po potrebi se v skupini izoblikujejo delovna telesa, vsekakor pa moramo izmed članov izbrati člane iniciativne ali organizacijske skupine, ki organizira skupino zainteresiranih udeležencev, pripravlja material za sestanke ter ureja druge potrebne zadeve $\mathrm{v}$ okviru izpeljave Lokalne agende 21 . Le-ta naj šteje okrog pet članov. V njej naj bi bili predstavniki občine, najpomembnejših podjetij ali organizacij ter predstavnik izvajalca.

\subsection{Metodologija za pripravo programa}

Program varstva okolja ali lokalne agende je zelo kompleksen. V pripravo je vključenih veliko posameznikov, obdela se vrsta tematik. Zato je pred začetkom potrebno postaviti metodologijo, ki pa je toliko fleksibilna, da jo lahko med procesom spreminjamo in dopolnjujemo.

Priprava programa po tem principu (Hewit 1997) je le ena izmed možnih poti. Navedene aktivnosti potekajo praviloma ena za drugo, vendar se je možno po vsakem koraku vrniti na katero izmed prejšnjih tematik, na izhodišče pa se vrnemo potem, ko določeno dejavnost zaključimo, saj ponovno ovrednotimo stanje. V praksi metodologijo pripravljamo od primera do primera, kajti vsako območje, ki ga obravnavamo, ima svoje značilnosti in zahteva individualni pristop.

Program varstva okolja v občini Žalec smo izdelali v dveh letih po metodologiji lokalne agende. Na delavnicah nismo obravnavali zgolj okoljskega področja, ampak smo se lotili tudi socialnega in gospodarskega. Tako je pripravljena osnova, da se program varstva okolja lahko dopolni v Lokalno agendo 21 za občino Žalec (Šterbenk s sodelavci 2002). Program mora svet občine še potrditi, potem pa bodo pričeli z njegovim izvajanjem. 
Sika 2: Priprava programa po Hewit 1997, str. 17.

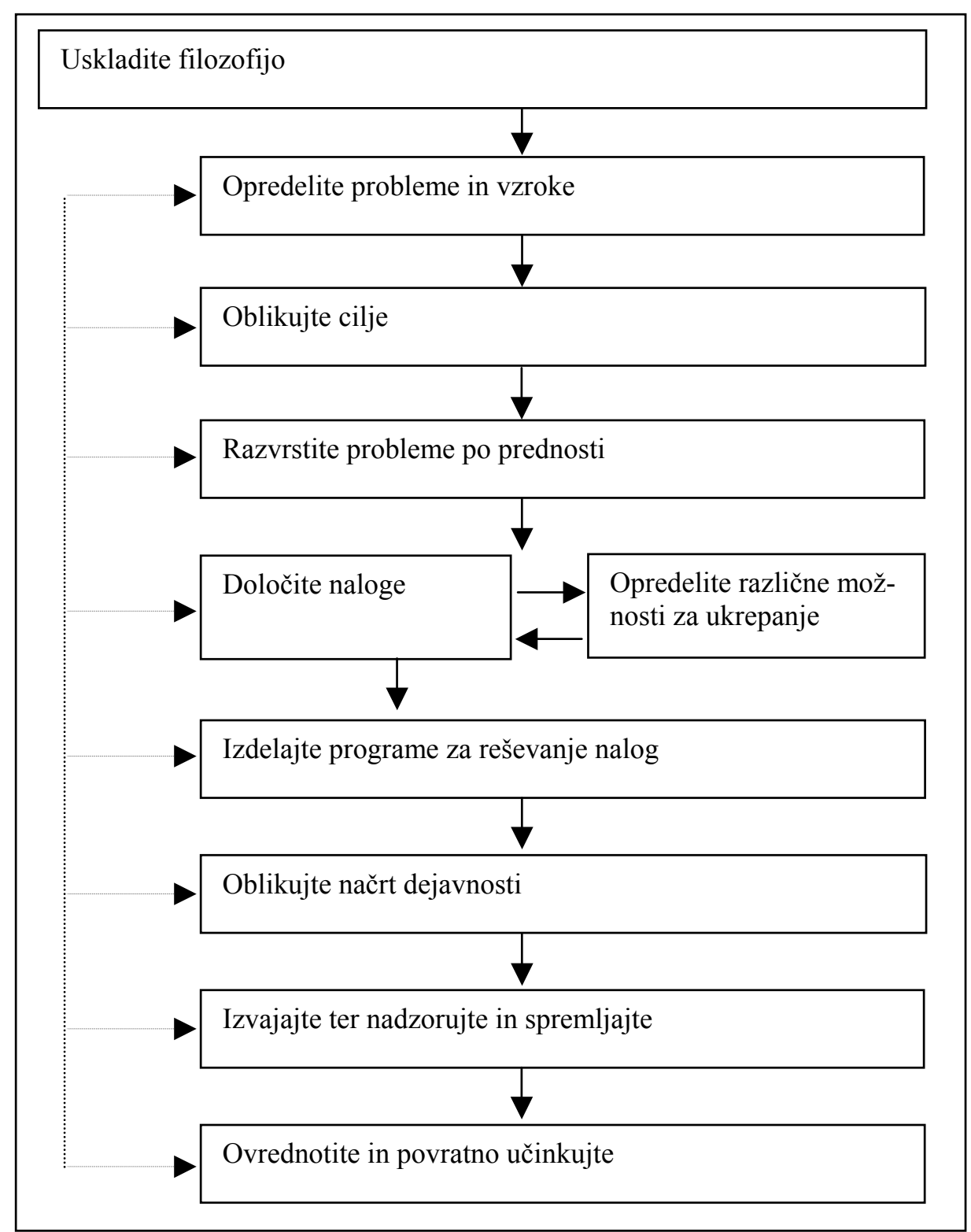


Slika 3: Metodologija izdelave Programa varstva okolja občine Žalec

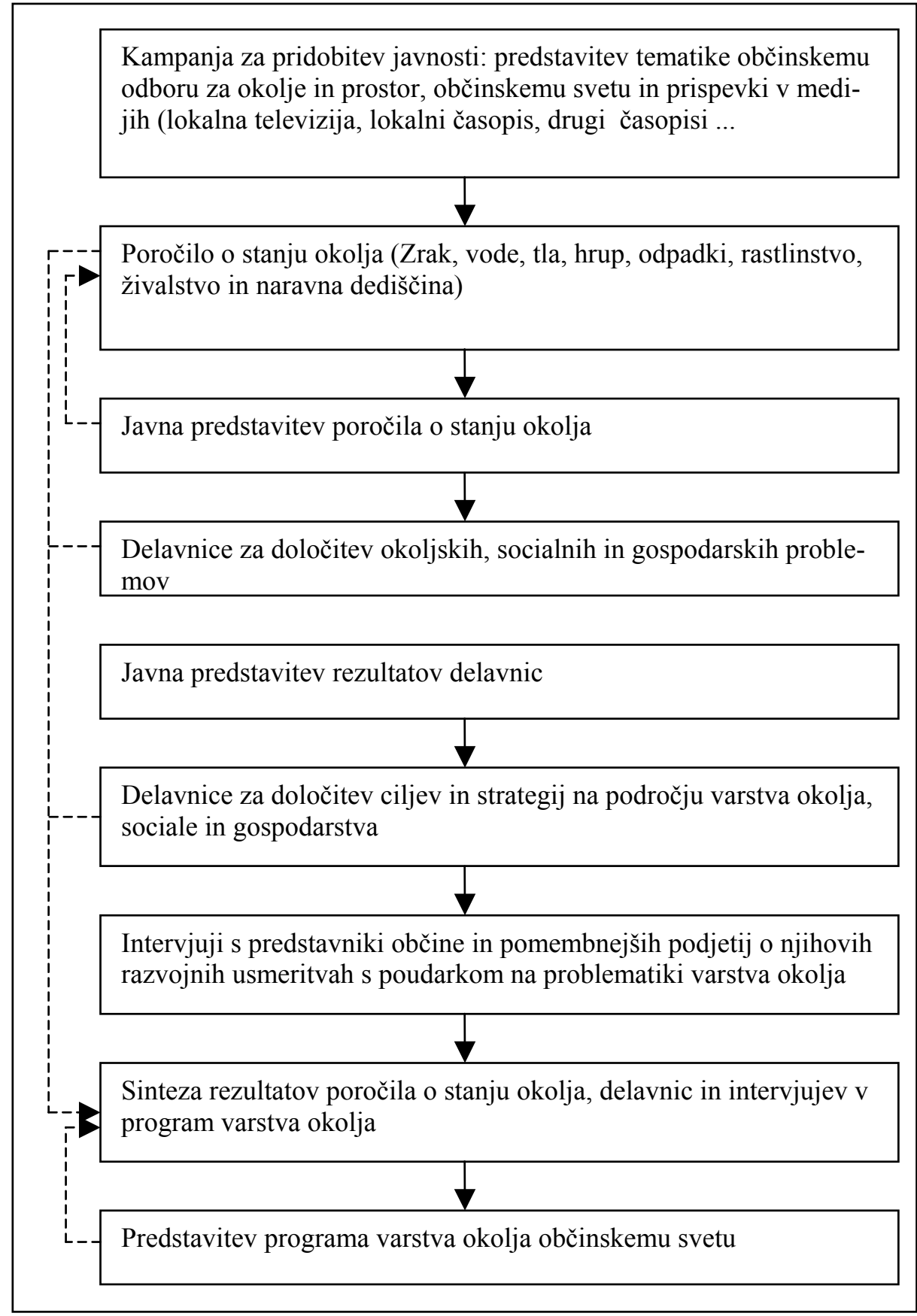




\subsection{Metodologija posameznih faz v pripravi programa}

Program varstva okolja oziroma lokalna agenda sta zelo kompleksna in interdisciplinarna projekta, ki ju sestavlja vrsta faz in dejavnosti. Vsaka faza ima svojo metodologijo, ki pa se od programa do programa in od izvajalca do izvajalca razlikuje. Pri fazah uporabljamo predvsem osnovne metode znanstvenega elaborata in skupinskega dela.

\section{POMEMBNI POUDARKI PRI PRIPRAVI LA OZIROMA PROGRAMA VARSTVA OKOLJA}

V prejšnjih točkah sta bila predstavljena pojma lokalna agenda 21 in program varstva okolja. Opisali smo tudi vsebini obeh dokumentov ter metodologijo izdelave. Pri pripravi različnih konkretnih programov smo pridobili precej izkušenj. Zato v nadaljevanju podajamo vsebine, pri katerih moramo biti še posebej pozorni.

\subsection{Informiranje javnosti}

Prvi korak programa oziroma agende je: pridobiti javnost k sodelovanju. Po naših izkušnjah so za to najprimernejši lokalni mediji (časopis, radio, televizija oziroma kabelski razdelilni sistem). Pomembne so tudi javne predstavitve, ki morajo biti logične, jedrnate in naj na koncu izzovejo diskusijo. S prisotnimi velja navezati dober stik, saj le tako lahko dobimo uporabne dodatne informacije. Izvajalci ta del največkrat zapostavimo, čeprav sodi med pomembnejše korake za pripravo realnega in uporabnega programa.

\subsection{Sestava zainteresirane skupine}

Uslužbenci občine so tisti, ki morajo imeti ključno vlogo pri sestavi zainteresirane skupine. Članom je potrebno takoj pojasniti, da je njihovo delo prostovoljno, neplačano, ampak zelo pomembno za nadaljnji razvoj. Na prvem sestanku (največkrat je to kakšna javna predstavitev ali delavnica) naj bi se dogovorili o načinu dela, času sestankov. To zahteva izkušenega moderatorja, ki zna razpravo voditi v produktivni smeri, tako da na koncu dobimo demokratično, strukturirano in rangirano mnenje. 


\subsection{Sodelovanje s predstavniki občinskih služb}

Programe varstva okolja oziroma Lokalne agende praviloma naročajo in koordinirajo občinski oddelki oziroma službe za varstvo okolja in urejanje prostora. Tako je sodelovanje $z$ le-temi navadno vedno dobro. Toda že pri programu varstva okolja je potrebno sodelovati z drugimi sektorji, kar pa je večkrat mnogo težje. Še širšo mrežo sodelavcev je potrebno vzpostaviti za lokalno agendo. Nemalokrat se primeri, da je medresorsko sodelovanje na občinah slabo, zato je naloga izvajalcev, da za sodelovanje motivirajo vse sektorje. Velikokrat ravno slaba komunikacija povzroči zamude pri pripravi programov.

\subsection{Podatki}

Zlasti pri manjših občinah izvajalci velikokrat ugotovimo, da ni na voljo veliko podatkov za pripravo programa. Takrat uporabimo statistične podatke in podatke državnih monitoringov. Na delavnicah je mogoče opredeliti veliko ciljev za prvo fazo programa tudi brez podatkov. V prvo fazo programa pa za cilj postavimo pridobitev podatkov o pojavu oziroma pokrajinskem elementu, ki je za tisto območje pomemben ali se je izkazal za problem. V naslednji fazi programa lahko potem določimo cilje in način, kako jih doseči.

\subsection{Intervjuji z vodstvi podjetij}

V praksi se mnogokrat izkaže, da je v skupino zainteresiranih zelo težko pridobiti predstavnike podjetij. Le-ta pa so glavni motorji razvoja, kot tudi praviloma najpomembnejši onesnaževalci. Za realen program vsekakor moramo poznati njihove razvojne potenciale in načrte. Če ne gre drugače moramo obiskati vodstva podjetij, jih seznaniti z vsebino programa, ki ga pripravljamo in njihove načrte vključiti med cilje. Pomembna naloga izvajalca je, da skozi program vzpostavi oziroma izboljša sodelovanje med podjetji, javnostjo in lokalno skupnostjo. Rezultat sodelovanja med vsemi tremi dejavniki ni zgolj boljši program, ampak predvsem hitrejše izboljševanje naravnega, gospodarskega in socialnega okolja. Večina podjetij ima svoje razvojne programe, ki jih je potrebno samo vključiti v občinskega. Rezultat tega je bolj usklajen občinski program in preprečevanje podvajanja različnih preventivnih in kurativnih ukrepov. 


\subsection{Organizacija in izvedba delavnic}

Po dosedanjih izkušnjah je najboljši čas za delavnice pozno jeseni, pozimi in zgodaj spomladi. Ljudi, ki bodo delavnice vodili je pametno seznaniti vsaj z osnovami moderatorstva, najbolje pa je, da jih napotite na kakšnega izmed tečajev moderatorstva. Priporočljivo je, da skupine ne štejejo več kot 6 do 7 ljudi, moderatorji pa morajo poskrbeti za prijetno in delovno vzdušje. Že na začetku moramo postaviti pravila obnašanja $\mathrm{v}$ skupini in dodeliti vloge posameznikom (vodja, zapisnikar, poročevalec, časomerilec ...) Ljudje morajo biti ves čas aktivno zaposleni (Toplak s sodelavci 2001). Delavnice lahko organiziramo med tednom popoldne. Če pa se udeleženci strinjajo, je dobra rešitev tudi sobota. Takrat je lahko delavnica vsebinsko bogatejša, delo pa intenzivnejše.

\subsection{Financiranje}

Programi varstva okolja in lokalne agende v Sloveniji so (praviloma) nizkoproračunski projekti Praksa kaže, da jih financirajo predvsem s sredstvi občinskih proračunov, ki so občasno podprti s sredstvi državnega proračuna. Praksa razvitih evropskih držav je, da lokalne agende sofinancirajo pomembnejša podjetja in ustanove v lokalni skupnosti. To pa ne pomeni le več denarnih sredstev, ampak tudi intenzivnejše sodelovanje gospodarstva pri načrtovanju in izvajanju programov ter višjo stopnjo informiranja in s tem večjo odmevnost projekta. Temu bi bilo potrebno posvečati več časa, vendar smo ponavadi izvajalci časovno omejeni zaradi nizkega proračuna projektov.

Primer široko podprte lokalne agende je Lokalna genda 21 Leipzig (WWW.LE-AGENDA.DE), ki jo poleg občine podpira še vrsta podjetij institucij in organizacij (Sparrkasse Leipzig, Stadtwerke Leipzig, Universität Leipzig, Leipziger Messe, Qelle, Umveltforschungszentrum in drugi).

\section{SKLEP}

Tako lokalna agenda kot program varstva okolja nista znanstveno raziskovalna projekta, ampak konkretna strokovna programa za približevanje trajnostnemu razvoju. Oba sta zelo zahtevna, kompleksna in zahtevata interdisciplinarni ter sistemski pristop. Ko se lokalna skupnost odloči za izdelavo enega od programov, je potrebno čimprej pričeti. Glede na to, da gre dejansko za procese, naš cilj ne more in ne sme biti popolnost. Proces moramo pričeti in po vsakem 
preverjanju bomo okolje in gospodarske ter socialne razmere ponovno ovrednotili ter cilje postavili na novo. Bistveno je, da se razmere na vseh razvojnih področjih stalno izboljšujejo. Program moramo vedno uskladiti z obstoječimi razvojnimi načrti in programi ter $\mathrm{k}$ sodelovanju pritegniti čimveč različnih (lokalnih) strokovnjakov, predstavnike podjetij in institucij ter javnosti. Cilji morajo biti realni in usklajeni s proračunskimi sredstvi oziroma sredstvi podjetij, ki obratujejo na obravnavanem območju. Ko program potrdi občinski svet, je potrebno določiti posameznike, ki bodo nosilci načrtovanih razvojnih nalog. Pomembnejše od popolnega programa je: s programom pričeti. Za odpravljanje pomanjkljivosti in vsebinsko dopolnjevanje bo dovolj časa $v$ naslednjih fazah. Le na takšen način lahko program varstva okolja oziroma lokalna agenda postaneta resničen razvojni proces lokalne skupnosti.

\section{Literatura in viri:}

Agenda 21, Programme of Acion for Sustainable Development, 1992. New York, United Nations Publications.

Agenda 21 za Slovenijo - prispevek nevladnih organizacij, 1995. Ljubljana, Umanotera. 44 str.

Hewitt, N., 1997. Priročnik za načrtovanje okoljskih dejavnosti - Evropski priročnik za načrtovanje Lokalnih agend 21. - ICLEI, UMANOTERA, Ljubljana. Slovenska fundacija za trajnostni razvoj, 64 str.

Laws, E.A., 2000. Aquatic Pollution. New York, Chischester, Weinheim, Brisbane, Singapore, Toronto, John Wiley \& Sons Inc. 639 str.

Pavšek, Z., Šterbenk, E. Kotnik, K, Savinek, K., Matjaž, Š, Ževart, M., Bole, M., Flis, J., 2000. Poročilo o stanju okolja v občini Žalec. Velenje, ERICo Velenje, delovno poročilo. 114 str.

Svetina, M., Flis, J., Špeh, N., 2000. Lokalna agenda 21 v Mestni občini Velenje (1. faza), Poročilo za leto 1999. Velenje, ERICo Velenje, delovno poročilo. 195 str.

Šterbenk, E., Šalej, M, Kotnik, K., Pavšek, Z., 2002. Program varstva okolja Lokalna agenda 21 za občino Žalec, zaključno poročilo. Velenje, ERICo Velenje, delovno poročilo. 36 str.

Toplak, C in sodelavci (urednica), 2001. Moderiranje skupinskih procesov, Priročnik za moderatorje. Ljubljana, Umanotera.

Viler-Kovač, A., Traunček, S., Štefelj, I., 1999. Varstvo okolja in upravni postopki. - Seminarsko gradivo. Ljubljana, GV Izobraževanje.

WWW. LE-AGENDA.DE

Zakon o varstvu okolja, 1993. Uradni list Republike Slovenije 32/93. 


\title{
OVERALL VIEW OF THE PREPARATION OF AN ENVIRONMENTAL PROTECTION PROGRAMME OR LOCAL AGENDA 21
}

\begin{abstract}
Summary
In Rio de Janeiro, in 1992, world leaders agreed on the urgency of applying the principles of sustainable development and adopted Agenda 21, a planetary programme for sustainability (Agenda 21 za Slovenijo ... 1995). So far exising development programmes were related only to market conditions and did not consider the environmental consequences of economic development. All environmental costs and the costs of exhausting of natural resources are incorporated in economic development planning according to Agenda 21. It is shown that global environmental aims can be realised only in the framework of local improvements. That is why local communities all over the world are implementing such local agendas. A Local Agenda 21 is a way towards sustainable development in which environmental, economic and social interests are equally represented.

In Slovenia more and more local communities are deciding to implement a local agenda. The majority of them are in fact environment protection programmes, which consider economic and social points of view on a lower level as local agendas. The departments for the environment and of spatial planning of local communities are usually the initiators in preparing such programmes; other departments are not equally involved in the preparation and implementation of local agendas. On the state level the situation is similar. Almost all local environment protection programmes and local agendas are discussed and co-financed by the Ministry of the Environment, Spatial planning and Energy. On the other hand, no Slovenian legal act contains the term Local Agenda 21.

A Local Agenda 21 (LA 21) is a realistic and achievable cyclic process which never ends. It can be said that LA 21 is a system of constant improvements toward sustainable development. LA 21 is a well balanced development programme, so representatives of the main driving forces for development of the area should be involved in its preparation. In the group for implementation of LA 21 representatives of the local community, companies, organisations and the public must be represented. The group defines a timeframe, the contents and the goals of the programme in cooperation with the performer of LA 21 . LA 21 is designed according to the particular situation in a specific municipality. The fundaments for an action plan are environmental, economic and social reviews. Same issues are discussed at workshops of the group for implementation of LA 21 and also the managing structures of companies and
\end{abstract}


organisations are interviewed about development issues. In the action plan data from all sources are compared and the main aims are chosen. The action programme contains development projects, their costs and priority and also names the organizations or persons responsible for carrying out the tasks. The curator of LA 21, who supervises its implementation, must be defined in the municipality. After a certain time period the results of LA must be reviewed and also new aims must be set. Each setting of new aims is a step toward sustainability.

According to the experiences of the ERICo Velenje Institute it is of great importance to inform the public in order to obtain relevant feedback and to establish cooperative relations. The best way to inform the public is through local newspapers, local radio and television. Also the organisation of public presentations, lectures and workshops is very useful. It must also not be forgotten to establish cooperative relations with representatives of the municipality. The members of the group for implementation of LA 21 must be chosen carefully. The data about environmental, economic and social conditions might be difficult to collect. In that case data should be obtained from state monitoring and statistics or from workshops and interviews of management structures of the local companies, municipality and organisations. Financing of the programmes is mainly dependent on the budget of the municipality and perhaps on some state aid. Also local companies and organisations should cofinance the process, not only for enlarging the budget, but also to increase their interest in designing and executing the programme.

The Environmental protection programme or LA 21 results in benefits for everyone in municipality. The inhabitants are better informed and they have a chance to influence local policy. The local community benefits from a development programme and companies improve their public relations. But there is an important point that needs to be made: perfection is not to be expected. The process must simply be started. Mistakes can be annulled during next steps of the programme. 